\title{
Effect of Supplemental Irrigation on Tuber Yield, Water Use Efficiency and Nitrogen Use Efficiency of Potato (Solanum Tuberosum L.) Grown in a Mollic Andosol
}

Felix SATOGNON ( $\nabla$ felixsatognon@gmail.com )

Egerton University Faculty of Agriculture https://orcid.org/0000-0002-1536-5251

Seth F.O. Owido

Egerton University Faculty of Agriculture

Joyce J. Lelei

Egerton University Faculty of Agriculture

\section{Research Article}

Keywords: Potato, Irrigation, N-fertilisation, Yield, WUE, NUE

Posted Date: April 27th, 2021

DOI: https://doi.org/10.21203/rs.3.rs-427233/v1

License: (9) This work is licensed under a Creative Commons Attribution 4.0 International License.

Read Full License

Version of Record: A version of this preprint was published at Environmental Systems Research on August 18th, 2021. See the published version at https://doi.org/10.1186/s40068-021-00242-4. 


\title{
Effect of supplemental irrigation on tuber yield, water use efficiency and nitrogen use efficiency of potato (Solanum tuberosum L.) grown in a mollic Andosol
}

\author{
Felix Satognon*, Seth F.O. Owido, Joyce J. Lelei \\ Department of Crops, Horticulture and Soils, Faculty of Agriculture, Egerton University \\ P. O. Box 536-20115, Egerton, Njoro, Kenya. Corresponding authors' email: \\ felixsatognon@gmail.com, +22997874536/+254740585119
}

\section{Abstract \\ Background}

The yield of potato (8.86 tonnes/ha), the second staple food and cash crop in Kenya is remained low due to a reduction in seasonal precipitation and low soil fertility. Drought or dry periods between rainfall seasons and increased temperatures, which leads to high crop evapotranspiration, are experienced in $70-80 \%$ of the smallholder farms. Among major elements require by potato, nitrogen is the most important influential element but it is deficient in most potato-growing soils in Kenya because of nutrient depletion with inadequate nutrient replenishment results from continuous production. Hence the introduction of supplemental irrigation with an adequate application of this nutrient could increase crop yields. Therefore, this study was conducted in Nakuru, one of the major potato growing areas in Kenya, to determine the effects of full supplemental irrigation (FI) and four nitrogen levels, $\mathrm{N} 0(0)$, $\mathrm{N} 1(60)$, N2(90) and N3(130 kg N/ha) on tuber yield, water use efficiency (WUE) and nitrogen use efficiency (NUE) of potato grown in a mollic Andosol in Kenya compared to conventionnel rain-fed potato production.

\section{Results}

The results showed that tuber yield, marketable tuber yield and NUE significantly differed due to the interaction effect between irrigation and $\mathrm{N}$-fertilization rate $(\mathrm{P}<0.001)$ whereas the WUE was statistically different due to the $\mathrm{N}$-fertilization rate $(\mathrm{P}<0.001)$. The highest tuber yield 58.28 tonnes/ha was found in supplemental irrigation with an application of $130 \mathrm{~kg} \mathrm{~N} / \mathrm{ha}$ treatment. Full supplemental irrigation treatment increased marketable yield by 129.84, 94.63, 151.21 and $126.63 \%$ for $0,60,90$ and $130 \mathrm{~kg} \mathrm{~N} / \mathrm{ha}$, respectively compared to rain-fed Nfertilization treatments. NUE increased statistically with an increase in $\mathrm{N}$ rate up to $90 \mathrm{~kg} \mathrm{~N} / \mathrm{ha}$, then tended to increase slightly as nitrogen rate increased further. An increase in potato tuber yield was positively correlated with number of tubers/plant $(r=0.75)$, NUE $(r=0.95)$, WUE $(\mathrm{r}=0.72)(\mathrm{P}<0.001)$.

\section{Conclusions}

The high potato yield and marketable tuber yield in mollic Andosol can be obtained when all water deficits of the growing season are eliminated with supplemental irrigation and an application of $130 \mathrm{~kg} \mathrm{~N} / \mathrm{ha}$ but it is essential to exploit water regimes for acceptable yield with water-saving.

Keywords: Potato, Irrigation, N-fertilisation, Yield, WUE, NUE

\section{Background}

Potato (Solanum tuberosum L.) is the second most important staple food in Kenya, after maize, and the production is predominantly rainfed (Muthoni et al., 2017). The area under production increased from 135,000 ha in 2008 to 217,315 ha in 2018. An estimated yield of 8.6 tonnes/ha was obtained in 2018, which was 60\% of yields achieved in 2008 (FAOSTAT, 2020; Mburu et al., 2020; McEwan et al., 2021). Research done to improve potato yield has generally focused on enhancing soil fertility, managing pests and introducing drought-resistant varieties and little attention have been given to optimizing nitrogen and water use efficiency for increased potato yields. Potato is sensitive to water deficit. Slight water stress causes a 
reduction in potato leaf number and size, canopy radiation interception and photosynthesis, which consequently affects the tuber number, size and yield (Li et al., 2016). Drought or dry periods between rainfall seasons and increased temperatures, which leads to high crop evapotranspiration, are experienced in 70-80\% of the smallholder farms (Bryan et al., 2013; Muthoni et al., 2017; Taiy et al., 2017; Kimathi et al., 2021). Previous research attributed the declining yield to the reduction of seasonal mean rainfall from $737 \mathrm{~mm}$ to $126 \mathrm{~mm}$ in the potato growing areas (Waaswa et al., 2021). Soils in most potato growing areas in Kenya are mollic Andosols. These soils become dry a few days after a rainfall event due to their high infiltration rates. Supplemental irrigation of $55 \mathrm{~mm}$ could increase potato yield up to $50.8 \%$ (Tang et al., 2018). Nitrogen and water management are critical in potato production in Kenya.

Water stress reduces nitrogen uptake as a result of the decreased water uptake and transpiration rate (Koch et al., 2020). Nitrogen deficiency is manifested by reduced growth and tuber yield in terms of tuber number and size (Koch et al. 2019). Integrating nitrogen with irrigation water significantly affects NUE. NUE of potato increases with irrigation water and nitrogen rates and high irrigation water application results in better NUE compared to low irrigation water (Badr et al., 2012). WUE increases with nitrogen level but decreases with an increase in the amount of irrigation water (Badr et al., 2012; Tolessa, 2019). The objective of the study was to determine the effects of supplementary irrigation and $\mathrm{N}$-fertilization rates on tuber yield, water use efficiency and nitrogen use efficiency of potato grown in a mollic Andosols in Kenya.

\section{Methods and Materials}

\section{Experimental site description}

A two-season field experiment was conducted between July and October 2020 and November and 2020 and January 2021 at the Agro-Science Park experimental farm of Egerton University in Nakuru County, Kenya. The experimental site is located in agro-ecological zone III of Kenya $\left(0.3031^{\circ} \mathrm{S}, 36.0800^{\circ} \mathrm{E}\right)$ at an altitude of $2670 \mathrm{~m}$ above sea level. Climatic factors including precipitation (figure 1), maximum and minimum temperature and humidity of the growing seasons (Table 1) were collected from the weather station of Egerton University located $1 \mathrm{~km}$ away from the experimental site.

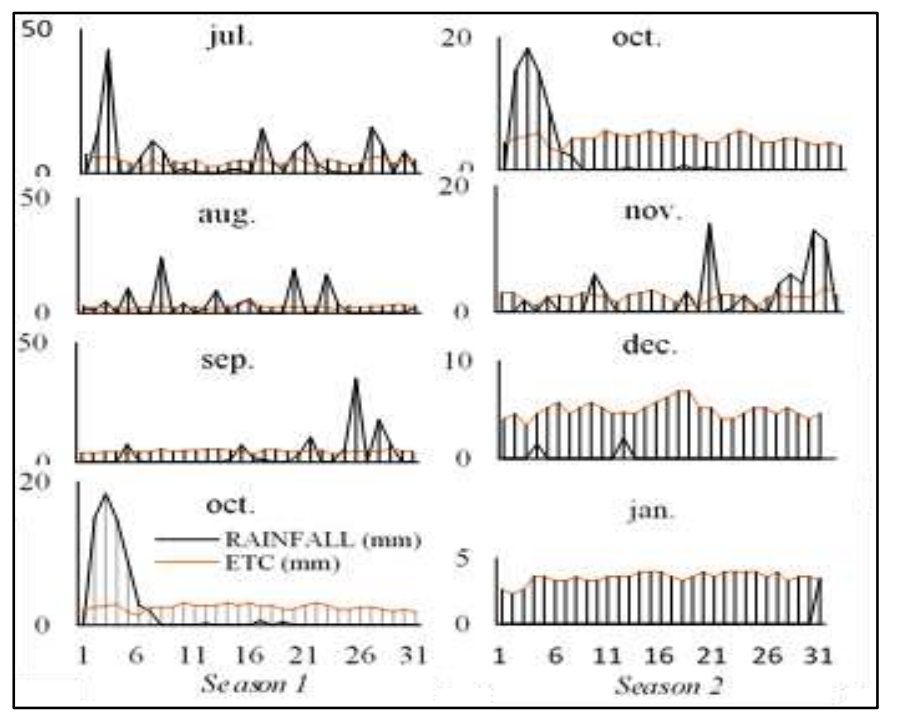

Figure 1: Daily precipitation and $\mathrm{ET}_{\mathrm{C}}$ of the growing seasons 
Table 1: Meteorological data from weather station of Egerton University

\begin{tabular}{|c|c|c|c|c|c|c|c|}
\hline Parameters & Jul & Aug & Sep & Oct & Nov & Dec & Jan \\
\hline$\overline{\text { Average of maximu }}$ & $\overline{23.2}$ & $\overline{23.8}$ & $\overline{24.1}$ & 25.2 & $\overline{23.4}$ & 24.2 & 25.1 \\
\hline of minimum temperature $\left({ }^{\circ} \mathrm{C}\right)$ & 10.5 & 10.7 & 9.5 & 10.1 & 10.2 & 9.9 & 10.0 \\
\hline Average of humidity (\%) & 49 & 48 & 51 & 49 & 49 & 53 & 57 \\
\hline
\end{tabular}

To determine initial properties, soil samples were randomly taken at two different depths (from $0-0.15$, and $0.15-0.45 \mathrm{~m})$ because potato rooting falls between $(0-0.4 \mathrm{~m})$. The samples were collected from six locations and mixed to obtain one composite sample per depth. The composite soil samples were dried at a constant temperature of $50^{\circ} \mathrm{C}$, crushed and sieved through a 2-mm sieve in preparation for baseline soil fertility analyses at the laboratory of Kenya Agricultural and Livestock Research Organisation (KALRO). Soil pH was determined in a $1: 1(\mathrm{w} / \mathrm{v})$ water extract. The total nitrogen content was determined using the Kjeldahl digestion method as described by Okalebo et al. (2002). In this method, the nitrogen of the sample is initially converted to ammonia by metal-catalyzed acid digestion (Motsara and Roy, 2008). The Cornell Morgan soil test was used to extract P, K, Mg, Ca, Mn, and $\mathrm{Zn}$ by shaking dried samples in a 1:5 (v/v) ratio for $30 \mathrm{~min}$ in Morgan solution (1 M sodium acetate buffered at pH 4.8; Morgan, 1941). The initial chemical properties are shown in table 2.

Table 2: Soil chemical analyses

\begin{tabular}{|c|c|c|c|c|}
\hline Soil depth $\mathrm{cm}$ & \multicolumn{2}{|c|}{$0-0.15 \mathrm{~m}$} & \multicolumn{2}{|c|}{$0.15-0.45$} \\
\hline Parameters & Value & Class & Value & Class \\
\hline Soil pH & 5.43 & medium acid & 5.46 & medium acid \\
\hline Exch. Acidity meq\% & 0.20 & adequate & 0.21 & Adequate \\
\hline Total Nitrogen $\%$ & 0.16 & low & 0.14 & Low \\
\hline Total Org. Carbon \% & 1.69 & moderate & 1.61 & Moderate \\
\hline Phosphorus ppm & 21 & low & 19.1 & Low \\
\hline Potassium meq\% & 1.14 & adequate & 1.11 & Adequate \\
\hline Calcium meq\% & 5.6 & adequate & 5.4 & Adequate \\
\hline Magnesium meq\% & 1.61 & adequate & 1.43 & Adequate \\
\hline Manganese meq $\%$ & 1.37 & adequate & 1.25 & Adequate \\
\hline Copper ppm & 1.80 & adequate & 1.71 & Adequate \\
\hline Iron ppm & 12.2 & adequate & 12.2 & Adequate \\
\hline Zinc ppm & 2.45 & low & 2.42 & Low \\
\hline Sodium meq $\%$ & 0.18 & adequate & 0.17 & Adequate \\
\hline
\end{tabular}

For water suitability for irrigation, water $\mathrm{pH}$ and conductivity (EC) were determined from a water sample with $\mathrm{pH}-$ meter and electrical conductivity meter respectively. $\mathrm{Na}$ and $\mathrm{K}$ were measured with a flame photometer while $\mathrm{Ca}$ and $\mathrm{Mg}$ were determined using AAS (Atomic Absorption Spectrophotometer). Chlorides were determined by titration with silver nitrate and potassium chromate while carbonates were measured as bicarbonates determined by titration with hydrochloric acid and phenolphthalein. Sulphates were determined using the turbid metric method. In this method, an aliquot of water sample mixed with gum acacia and barium chloride crystals was taken and the turbidity was measured with the spectrophotometer at $440 \mathrm{~nm}$. Sodium absorption ratio was computed using sodium, calcium and magnesium concentrations. Water had a medium salinity level and sulphates content was at a high level (table 3 ). The quality of water used was suitable for irrigation since the soil is permeable with adequate drainage (this interpretation was based on USDA classification of irrigation water) (Wilcox, 1955; Scherer et al., 1996; Bauder et al., 2011) 
Table 3: Suitability of irrigation water

\begin{tabular}{ll}
\hline $\mathrm{pH}$ & 8.09 \\
Conductivity (EC) mS/cm & 0.27 \\
Sodium, meq/litre & 0.37 \\
Potassium, meq/litre & 0.12 \\
Calcium, meq/litre & 0.04 \\
Magnesium, meq/litre & 0.05 \\
Carbonates, meq/litre & $\mathrm{ND}^{*}$ \\
Bicarbonates, meq/litre & 0.75 \\
Chlorides, meq/litre & 1.92 \\
Sulphates, meq/litre & 49.9 \\
Sodium Adsorption Ratio & 1.74 \\
\hline
\end{tabular}

Soil texture with the percentage of each primary soil (sand, silt, and clay) was determined using the hydrometer method (Bouyoucos, 1962). Soil bulk density ( $\rho b)$ was determined using the gravimetric method followed by oven-dry (Blake, 1965). Field Capacity (FC) was measured using oven-dry method (at $105{ }^{\circ} \mathrm{C}$ for 24 hours) (Aschonitis et al., 2013). Permanent Wilting Point (PWP) was measured after subjecting the samples to a pressure of 1.5 bar. Available Water (AW) was computed by subtracting the permanent wilting point from the field capacity using equation 82 of FAO 56 (Allen et al., 1998).

$$
\mathrm{AW}=1000(\theta \mathrm{FC}-\theta \mathrm{WP})
$$

where AW is the total available soil water in the plant root zone [mm], $\Theta_{\mathrm{FC}}$ is the water content at field capacity $\left[\mathrm{m}^{3} \mathrm{~m}^{-3}\right], \Theta_{\mathrm{wP}}$ is the water content at wilting point $\left[\mathrm{m}^{3} \mathrm{~m}^{-3}\right], \mathrm{Z}_{\mathrm{r}}$ is the rooting depth $[\mathrm{m}]$.

The Readily available water (RAW) which is the fraction of AW that a crop can deplete from the root zone without experiencing water stress was estimated using equation 83 of FAO 56 (Allen et al., 1998).

$\mathrm{RAW}=\mathrm{p} A \mathrm{~W}$

where RAW the readily available soil water in the plant root zone $[\mathrm{mm}], \mathrm{p}$ average fraction of AW that can be extracted from the root zone before water stress (reduction in ET) occurs [01]. The $\mathrm{p}$ average fraction of potato is 0.35 taken from table...83 of FAO 56 (Allen et al., 1998). The physical soil properties of the experimental site are shown in table 4.

Table 4: Physical properties of the experimental soil

\begin{tabular}{|c|c|c|c|c|c|c|c|c|c|}
\hline \multirow{2}{*}{$\begin{array}{l}\text { Depth } \\
\text { (m) }\end{array}$} & \multicolumn{4}{|c|}{ Soil texture } & \multicolumn{4}{|c|}{ Moisture Retention \% } & \multirow{2}{*}{$\begin{array}{l}\text { Bulk } \\
\text { Density } \\
\left(\mathrm{g} / \mathrm{cm}^{3}\right)\end{array}$} \\
\hline & Sand $\%$ & Silt \% & Clay \% & Class & $\mathrm{FC}$ & PWP & AW & RAW & \\
\hline $0-0.15$ & 63.7 & 26.2 & 10.1 & $\overline{\mathrm{SL}}$ & 19.9 & 12.3 & $\overline{7.6}$ & 2.66 & 1.26 \\
\hline $0.15-0.45$ & 57.6 & 30.2 & 12.2 & SL & 20.3 & 11.8 & 8.5 & 2.98 & 1.34 \\
\hline
\end{tabular}

$\mathrm{SL}=$ Sand Loam

\section{Experimental design and treatments}

Soil was ploughed at $0.2 \mathrm{~m}$ depth after which the plots were prepared by raising the soil. The experiment was laid out in a split-plot within a randomized complete block design with the irrigation treatments as the main plots and the four nitrogen levels as subplots since irrigation required a large plot. Each treatment was replicated in three different blocks. Each block was separated by $1.5 \mathrm{~m}$ and irrigation plots in each block were separated by $1.5 \mathrm{~m}$. Subplots within the main plots were separated by a $1.5 \mathrm{~m}$ buffer. Each experimental plot measured $7.5 \mathrm{~m}^{2}(5$ 
$\mathrm{m} \times 1.5 \mathrm{~m}$ ) and $0.4 \mathrm{~m}$ depth. Each plot received 20 apical rooted cuttings of Shangi potato variety at a spacing of $0.3 \mathrm{~m}$ and $0.70 \mathrm{~m}$ between rows and lines, respectively in set of five rows. This gave a density of 47,617 plants/hectare. Apical rooted cuttings of Shangi potato variety were planted on 7 Jul. 2020 and 9 Oct. 2020 and tubers were manually harvested from the six plants in the centre on 8 Oct. 2020 and 20 Jan. 2021. During planting, $90 \mathrm{~kg} / \mathrm{ha}$ of potassium sulphate (SOP) and $50 \mathrm{~kg} / \mathrm{ha}$ of triple superphosphate (TSP) fertilizers were added to each plot based on the universal recommendations of the area.

Irrigation treatments included FI (100\%ETC) and RF. Supplementary irrigation was made through drip irrigation method. Lateral driplines with $1.6 \mathrm{~L} \mathrm{~h}^{-1}$ at $100 \mathrm{kPa}$ inline drippers spaced at $30 \mathrm{~cm}$ were placed for each row. All plots were irrigated at the same level of water (during the first two weeks to encourage the crop establishment) but thereafter irrigation was daily scheduled to deliver the calculated quantity of water. For FI treatment, irrigation was made after the rain once $40 \%$ of available water was depleted. Available water was monitored using a TDR moisture meter and irrigation was applied daily based on crop evapotranspiration.

The N-fertilization treatments comprised N0(0), N1(60), N2(90) and N3(130 kg N/ha). All the $\mathrm{N}$-fertilization treatments were split applied at $10(40 \%), 30(40 \%)$ and $50(20 \%)$ days after planting. Urea fertilizer was used as a source of Nitrogen. Ridomil Gold MZ $68 \mathrm{WG}(1 \mathrm{~kg} / \mathrm{ha})$ combined with mancozeb $(1 \mathrm{~kg} / \mathrm{ha})$ fungicides were used to control the prevailing diseases especially the early and late blight diseases whereas VOLTAGE 5EC (350 ml/ha) was used to control potato pests. Weeding and earthing up were manually done one month after planting.

\section{Crop Water Requirements}

Reference crop evapotranspiration (ET $)_{0}$ was estimated daily using Penman-Monteith's (Allen et al., 1998; Jensen and Allen, 2016)

$$
\mathrm{ET}_{0}=\frac{\Delta(R n-G)+\rho_{a} c_{p}\left(\frac{\mathrm{es}-\mathrm{ea}}{\mathrm{ra}}\right)}{\Delta+\gamma\left(1+\frac{\mathrm{rs}}{\mathrm{ra}}\right)}
$$

where ETo $=$ reference evapotranspiration; $\Delta=$ slope of vapor saturation pressure; $\mathrm{Rn}=$ net radiation; $\mathrm{G}=$ soil heat flux; $\rho_{a}=$ mean air density at constant air pressure; $\mathrm{cp}=$ specific heat of the air; es - ea = vapour pressure deficit; = psychrometric constant; $r$ s = surface resistance; ra $=$ aerodynamic resistance. The actual crop evapotranspiration (ETc) was computed as the product of $\mathrm{ET}_{0}$ and crop coefficient $(\mathrm{Kc})$.

$$
E T_{C}=K_{C} \times E T_{0}
$$

The crop coefficient at different crop stages was calculated using the formulae 59, 62 and 65 of FAO (Allen et al., 1998). The average values of $\mathrm{Kc}$ at different crops stage are Kc initial = 1.14 and $1.18, \mathrm{Kc}$ developmental $=0.75$ and $0.78, \mathrm{Kc}$ middle $=1.12$ and $1.14, \mathrm{Kc}$ maturity $=$ 0.63 and 0.65 for the first and second season, respectively (table 5). The different stages of potato are initial stage, 25 days; growth stage, 30 days; middle stage, 30 days; and tuber maturity stage, 30 days.

Soil moisture content was computed over the growing season using a soil water balance equation (Steele et al., 1997 and Jensen and Allen, 2016). Seasonal actual potato evapotranspiration (ETa) was estimated using a water balance equation (Sharma et al., 2017):

$$
E T a=P+I \pm \Delta s-R-D
$$

Where $\mathrm{P}$ is the amount of precipitation throughout the potato growing season, $\mathrm{I}$ is the amount of irrigation supplied during the growing season of potato $(\mathrm{mm}), \Delta \mathrm{S}=$ change in soil water content in the root zone during the growing season of potato $(\mathrm{mm}), \mathrm{R}=$ runoff loss $(\mathrm{mm})$ and $\mathrm{D}$ is loss due to deep drainage during the growth period $(\mathrm{mm})$. $\mathrm{R}$ is ignored since the slope of 
the experimental site is relatively small with adequate soil infiltration and irrigation supplied through drip irrigation. Loss due to deep drainage (D) was expected to occur when rainfall surpassed the soil water deficit (which is estimated as field capacity minus soil water content before a rain) in the root zone before precipitation. Irrigation never surpassed the soil water deficit level and, thus, was considered to cause no loss due to deep drainage.

Table 5: Monthly average of $\mathrm{K}_{\mathrm{c}}, \mathrm{ET}_{0}$ and $\mathrm{ET}_{\mathrm{c}}$

\begin{tabular}{|c|c|c|c|c|c|c|c|c|}
\hline \multirow[b]{2}{*}{ Months } & \multicolumn{4}{|c|}{ Season 1} & \multicolumn{4}{|c|}{ Season 2} \\
\hline & Jul & Aug & Sep & Oct & Oct & $\mathrm{Nov}$ & Dec & Jan \\
\hline $\mathrm{Kc}$ & $\overline{1.14}$ & 0.75 & $\overline{1.12}$ & 0.63 & 1.18 & 0.78 & 1.14 & 0.65 \\
\hline ETo (mm) & 3.49 & 3.57 & 4.2 & 4.3 & 3.08 & 3.08 & 4.32 & 4.5 \\
\hline ETc (mm) & 4.63 & 4.32 & 5.32 & 4.93 & 4.26 & 3.86 & 5.46 & 5.15 \\
\hline
\end{tabular}

\section{Yield components}

Plant height, number of branches, biomass, number of tubers per plant, total tuber yield and marketable yield were collected as yield components from six plants from the centre of each subplot. Harvest index was expressed as the percentage of tuber yield in tonnes/ hectare.

$$
\mathrm{HI}(\%)=\frac{\text { Tuber Yield (tonnes } / \mathrm{ha})}{\text { total biomass at harves }(\text { tonnes } / \mathrm{ha})} \times 100
$$

\section{Water Use Efficiency and Irrigation Water Use Efficiency}

Water use efficiency (WUE) and Irrigation Water Use Efficiency (IWUE) were computed using the following equations (Erdem et al., 2006).

$$
\begin{gathered}
\text { WUE }\left(\mathrm{kg} \mathrm{m}^{-3}\right)=\frac{\text { Tuber Yield }(\mathrm{kg} / \mathrm{ha})}{E T a\left(\mathrm{~m}^{3}\right)} \\
\text { IWUE }\left(\mathrm{kg} \mathrm{m}^{-3}\right)=\frac{\text { TYI (tonnes } / \mathrm{ha})- \text { TYNI }(\mathrm{kg} / \mathrm{ha})}{\mathrm{I}\left(\mathrm{m}^{3}\right)}
\end{gathered}
$$

Where TYI is the tuber yield in $\mathrm{kg} / \mathrm{ha}$ of an irrigated plot, TYNI is the tuber yield in $\mathrm{kg} / \mathrm{ha}$ of a non-irrigated plot and $\mathrm{I}$ is the amount of irrigation supplied during the growing season of potato $\left(\mathrm{m}^{3}\right)$.

\section{Nitrogen Use Efficiency}

Nitrogen Use Efficiency (NUE) was determined using the following formula: (Leal Filho et al., 2015).

$$
N U E\left(\mathrm{~kg} \mathrm{~kg}^{-1}\right)=\frac{\text { Yield of } \mathrm{N} \text { fertilized plot in } \mathrm{kg}-\text { Yield of unfertilized plot in } \mathrm{kg}}{\text { Quantity of } \mathrm{N} \text { applied in } \mathrm{kg}}
$$

\section{Data analysis}

Before analysis, the Shapiro Wilk test at the probability of $\leq 0.05$ was run in R software to test the normality of the data. For any data that was not normally distributed, fitting data transformation was done. Analysis of variance (ANOVA) was run using R software (version 3.6.3). The least Significant Difference (LSD) test was used to separate the means of each treatment at a probability level of $<0.05$. Regression analyses at $5 \%$ were carried out to determine the potato growth and yield response to the nitrogen levels in mollic Andosols. During the analysis, any outlier data and not due to the treatment effect was deleted from the model. 


\section{Results and Discussion}

\section{Crop water requirement and Crop evapotranspiration}

For the first two weeks, $6.4 \mathrm{~mm}$ and $0 \mathrm{~mm}$ (because plots were not irrigated at the beginning of the second season due to the uniform rainfall) of water was used to encourage root establishment at the beginning of the first and the second season, respectively. The cumulative actual crop evapotranspiration was 268.09 and $237.7 \mathrm{~mm}$; for RF; and 359.47 and $381.89 \mathrm{~mm}$ for FI treatment; during the first and the second growing season, respectively. The amount of supplemental irrigation was 91.38 and $144.19 \mathrm{~mm}$ for seasons one and two, respectively. This showed that the crop water requirement was higher during the second season than the first season. This was due to the variation of rainfall patterns in the growing season (low and erratic rainfall with high temperatures) with a consequence of increasing crop evapotranspiration (Muthoni et al., 2017). Previous studies reported that the total seasonal potato ETa varied from 350 to $800 \mathrm{~mm}$ for various climates and environment (Ati et al., 2010; Ati et al., 2012; Paredes et al., 2018; Nowacki, 2018; Ierna and Mauromicale, 2018; Adavi et al., 2018; Afzaal et al., 2020; Meligy et al., 2020; Djaman et al., 2021).

\section{Yield components}

The effects of supplemental irrigation and N-fertilization on yield components (plant height, number of branches and tubers/plant, yield, HI and the marketable yield) during the growing seasons are presented in table 6 . The irrigation treatments had a significant effect on the number of tubers/plant ( $\mathrm{P}<0.05)$, yield ( $\mathrm{P}<0.001)$, and the marketable yield $(\mathrm{P}<0.001)$ but no effect on plant height, number of branches/plant and HI $(\mathrm{P}>0.05)$. However, the yield components plant height $(\mathrm{P}<0.001)$, number of branches $(\mathrm{P}<0.01)$, tubers/plant $(\mathrm{P}<0.001)$, yield $(\mathrm{P}$ $<0.001)$, HI $(\mathrm{P}<0.05)$ and the marketable yield $(\mathrm{P}<0.001))$ were significantly affected by $\mathrm{N}-$ fertilization treatments. Irrigation $\times \mathrm{N}$-fertilization interaction was significant for the tuber yield, number of tuber/plant, and the marketable yield $(\mathrm{P}<0.001)$ but was not significant for plant height, number of branches/plant, and HI $(\mathrm{P}>0.05)$.

Table 6: ANOVA table for plant height, number of branches/plant, number of tubers/plant, yield, HI and marketable yield

\begin{tabular}{|c|c|c|c|c|c|c|c|}
\hline $\begin{array}{l}\text { Source of } \\
\text { variation }\end{array}$ & $\mathrm{df}$ & $\begin{array}{l}\text { Plant } \\
\text { height }\end{array}$ & $\begin{array}{l}\text { Number of } \\
\text { branches/plan } \\
\mathrm{t}\end{array}$ & $\begin{array}{l}\text { Number of } \\
\text { tubers/plant }\end{array}$ & Yield & $\mathrm{HI}$ & $\begin{array}{l}\text { Marketable } \\
\text { yield }\end{array}$ \\
\hline Season & 1 & 226.03 & 455.53 & 107.97 & 42.84 & 268.94 & 131.50 \\
\hline $\begin{array}{l}\text { Replicatem(Seas } \\
\text { ons) }\end{array}$ & 4 & 140.23 & 41.74 & 10.04 & 11.08 & 36.49 & 4.45 \\
\hline Irrigation & 1 & 914.73 & 6.89 & $225.37 *$ & $5172.76 *$ & $\begin{array}{l}1422.0 \\
1\end{array}$ & $4942.84 *$ \\
\hline $\begin{array}{l}\text { Seasons*Irrigatio } \\
\text { n (Main plot } \\
\text { error) }\end{array}$ & 1 & 349.27 & 6.40 & 2.36 & 74.12 & 96.84 & 33.05 \\
\hline $\mathrm{N}$-fertilization & 3 & $618.75 * * *$ & $44.85^{* *}$ & $134.62 * * *$ & $\begin{array}{l}1005.90 * * \\
*\end{array}$ & $\begin{array}{l}108.54 \\
*\end{array}$ & $993.62 * * *$ \\
\hline $\begin{array}{l}\text { Nitrogen*Irrigati } \\
\text { on }\end{array}$ & 3 & 54.47 & 17.83 & $23.72 * *$ & $249.89 * * *$ & 49.90 & $200.94 * * *$ \\
\hline Error & 34 & 44.12 & 7.51 & 4.11 & 9.50 & $40.56^{*}$ & 6.33 \\
\hline $\mathrm{CV}$ & & 9.73 & 16.02 & 12.10 & 9.77 & 12.55 & 0.97 \\
\hline $\mathrm{R}^{2}$ & & 0.73 & 0.76 & 0.85 & 0.97 & 0.63 & 9.60 \\
\hline
\end{tabular}


Table 7: Means separation of plant height, number of branches/plant and HI (\%)

\begin{tabular}{lccc}
\hline & Plant height $(\mathrm{cm})$ & Number of branches/plant & HI $(\%)$ \\
\hline Irrigation effect & & & \\
FI & 72.58 & 17 & 56.29 \\
RF & 63.85 & 16 & 45.41 \\
LSD & $\mathrm{ns}$ & $\mathrm{ns}$ & $\mathrm{ns}$ \\
Nitrogen effect & & & \\
N3 & $76.82 \mathrm{a}$ & $19 \mathrm{a}$ & $54.69 \mathrm{a}$ \\
N2 & $69.35 \mathrm{~b}$ & $18 \mathrm{a}$ & $51.69 \mathrm{ab}$ \\
N1 & $67.36 \mathrm{~b}$ & $17 \mathrm{a}$ & $49.12 \mathrm{~b}$ \\
N0 & $59.35 \mathrm{c}$ & $14 \mathrm{~b}$ & $47.91 \mathrm{~b}$ \\
LSD & 5.51 & 2.27 & 5.29 \\
\hline
\end{tabular}

ns=not significant, Alpha $=0.05$

The average plant heights during the two growing seasons in FI was higher than RF but did not differ significantly and this is in line with previous research of Darabad (2014). However, the early studies found out that potato crop height increased with an increased amount of irrigation water (Farrag et al., 2016; Zhang et al., 2017; Metwaly and El-Shatoury, 2017). The same comparison across the $\mathrm{N}$ fertilization treatments showed an increase in plant height with an increase in nitrogen rate. The same result was found by previous research (Tolessa et al., 2017; Godebo and Belay, 2020; Setu and Mitiku, 2020). The number of branches/plant and HI significantly increased with an increase in nitrogen rate (table 7).

The FI significantly increased $(\mathrm{P}<0.001)$ the number of tubers/plant, tuber yield and marketable yield compared with $\mathrm{RF}$, regardless of $\mathrm{N}$-fertilization treatments. For different irrigation treatments, the number of tubers/plant, tuber yield and marketable yield ranged from 16 to 20 and 13 to $18,21.45$ to 39.73 and 20.86 to 44.11 tonnes/ha, and 15.23 to 33.87 and 16.83 to 38.83 tonnes/ha for the first and the second season, respectively and the tuber yield and marketable yield were higher during the second growing season. The previous research found that the potato is very susceptible or sensitive to water stress compared to many other crops and FI leads to high potato yield (Darabad, 2014; Mattar et al., 2021). Tuber initiation to maturity growth period forms the critical water requirement period where water deficits affect potato productivity (Salter and Goode, 1967; Sasani et al., 2006; Ahmadi et al., 2010). Begum et al. (2018) found out that irrigation water is very important for potato production due to the high yield of potato in a short time and if shortage of readily available water in the soil is eliminated by irrigation it is possible to achieve high and stable yields of potatoes, at the level of 40-50 tonnes/ ha or more. Previous studies found an increase in number of tubers/plant and marketable potato yield of irrigated potato compared to rain-fed production (Abu El-Fotoh et al., 2019; Waqas et al., 2021; Djaman et al., 2021). Djaman et al. (2021) also reported that the highest number of tubers per plant is obtained in FI.

It was also reported that $\mathrm{N}$-fertilization significantly increased number of tubers/plant, tuber yield and marketable yield (Badr et al., 2012). Number of tubers/plant, tuber yield and marketable yield across $\mathrm{N}$-fertilization treatments varied from 13 to 23 and 13 to $19,22.75$ to 40.69 and 22.18 to 45.06 tonnes/ha, and 16.12 to 34.53 and 17.50 to 39.84 tonnes/ha for season one and two, respectively. Early works found that potato yield and marketable potato yield, regardless of irrigation treatment, increased statistically with an increase in $\mathrm{N}$ rate up to $280 \mathrm{~kg}$ $\mathrm{N} / \mathrm{ha}$, then tended to increase faintly as nitrogen rate increased further (Badr et al., 2012; Ospina et al., 2014; Shunka et al., 2017). Further research needs to be done to determine the optimal nitrogen level for potato production in mollic Andosols. 
An interaction effect of Irrigation $\times$ Nitrogen was found for number of tubers/plant, tuber yield and marketable yield $(\mathrm{P}<0.001)$. The highest number of tuber/plant $(27)$ was obtained in $\mathrm{FI} \times \mathrm{N} 3$ treatment during the first season. In contrast, the lowest value of number of tubers/plant (11) was found in $\mathrm{RF} \times \mathrm{N} 0$ treatment of the second growing season (figure $2 \mathrm{a}$ and $\mathrm{b}$ ). Besides, the highest tuber yield (62.12 tonnes/ha) and marketable yield (55.79 tonnes/ha) were found in FI $\times \mathrm{N} 3$ treatment during the second season whereas the lowest tuber yield (15.21 tonnes/ha) and marketable yield (9.99 tonnes/ha) were found in FI $\times \mathrm{N} 3$ treatment during the second season and the first season, respectively (figure $2 \mathrm{c}, \mathrm{d}, \mathrm{e}$, and $\mathrm{f}$ ). FI treatment increased marketable yield by $129.84,94.63,151.21$ and $126.63 \%$ for $\mathrm{N} 0, \mathrm{~N} 1, \mathrm{~N} 2$ and $\mathrm{N} 3$, respectively compared to rainfed $\mathrm{N}$-fertilization treatments. An interaction effect of irrigation $\times \mathrm{N}$-fertilization was also reported by (Badr et al., 2012). Nitrogen and irrigation have significant interactive effects on potato yield and quality (Tolessa, 2019). Tang et al. (2018) reported that supplemental irrigation of $55 \mathrm{~mm}$ could increase potato yield up to $50.8 \%$ compared to the rain-fed production.

\section{Water use efficiency and irrigation water use efficiency}

Data on irrigation water use efficiency (WUE) and water use efficiency (IWUE) for all treatments are presented in table 8 and 9. The ANOVA table on WUE showed that the Nfertilization treatments $(\mathrm{P}<0.001)$ effect was significant in WUE and tuber yield whereas the irrigation and interaction effect was not significant. Comparison across irrigation treatments showed that FI produced the higher WUE $(11.77 \mathrm{~kg} / \mathrm{m} 3)$ in comparison to RF $(9.75 \mathrm{~kg} / \mathrm{m} 3)$ but they did not differ significantly. Different $\mathrm{N}$-fertilization treatments resulted in a significant increase in water use efficiency (WUE) compared with the control treatment. Moreover, Nfertilization treatments $\mathrm{N} 3(14.24 \mathrm{~kg} / \mathrm{m} 3)$ produced higher WUE followed by N2 (11.69 $\mathrm{kg} / \mathrm{m} 3), \mathrm{N} 1\left(9.64 \mathrm{~kg} / \mathrm{m}^{3}\right)$ and N0 $\left(7.47 \mathrm{~kg} / \mathrm{m}^{3}\right)$ (figure $2 \mathrm{~g}$ and $\mathrm{h}$ ). Previous studies found an increase in WUE with an increase nitrogen rate (Badr et al., 2012; Tolessa, 2019). Nfertilization significantly affected IWUE (P <0.001). IWUE of $\mathrm{N}$-fertilization treatments $\mathrm{N} 3$ and $\mathrm{N} 2$ were high but did not differ from each other. However, N-fertilization treatments N3 and $\mathrm{N} 2$ significantly differed from $\mathrm{N} 1$ and N0. The highest value of IWUE was obtained in N3 $\left(27.13 \mathrm{~kg} / \mathrm{m}^{3}\right)$ whereas the lowest in $\mathrm{N} 0\left(10.10 \mathrm{~kg} / \mathrm{m}^{3}\right)$ (figure $2 \mathrm{i}$ and $\mathrm{j}$ ).

\begin{tabular}{lll} 
Table 8: ANOVA table of WUE & & \\
\hline Source of variation & Df & WUE \\
\hline Season & 1 & 23.41 \\
Replicate(Seasons) & 4 & 4.36 \\
Irrigation & 1 & 48.72 \\
Seasons*Irrigation (Main plot error ) & 1 & 40.04 \\
Nitrogen & 3 & $100.20 * * *$ \\
Nitrogen $*$ Irrigation & 3 & 2.16 \\
Error & 34 & 1.45 \\
$\mathrm{CV}$ & & 11.22 \\
$\mathrm{R}^{2}$ & & 0.90 \\
\hline Signif. codes: 0 '***' 0.001 '**’ 0.01 '*’ & 0.05
\end{tabular}


Table 9: ANOVA table of IWUE

\begin{tabular}{lll}
\hline Source of variation & df & IWUE \\
\hline Season & 1 & 100.21 \\
Replicate & 2 & 2.42 \\
Nitrogen & 3 & $386.72 * * *$ \\
Error & 17 & 17.18 \\
$\mathrm{CV}$ & \multicolumn{2}{c}{23.08} \\
$\mathrm{R}^{2}$ & \multicolumn{2}{c}{0.82} \\
\hline Signif. codes: 0 '***' $0.001^{\text {'**' }} 0.01^{\text {'*’ }} 0.05$
\end{tabular}

\section{Nitrogen use efficiency}

Irrigation, $\mathrm{N}$-fertilization and interaction between $\mathrm{N}$-fertilization $\times$ Irrigation significantly affected the nitrogen use efficiency (table 10). Significantly the highest and lowest NUE were obtained from FI treatment $(197.22 \mathrm{~kg} / \mathrm{N} \mathrm{kg})$ and RF treatment $(72.69 \mathrm{~kg} / \mathrm{N} \mathrm{kg})$, respectively. The same trend was found by previous works (Badr et al., 2012; Tolessa et al., 2017). NUE was greatly affected by the $\mathrm{N}$ rate and increased as the $\mathrm{N}$ level was increased. Significantly the highest NUE was recorded N-fertilization N3. However, it was not significantly different from that of N2. The lowest was obtained at N1. This is in line with the study of (Badr et al., 2012). On the contrary, Banerjee et al. (2015) found out that NUE decreased with an increase in N rate. For the interaction, the highest value of NUE was recorded at FI $\times N 3(236.44 \mathrm{~kg} / \mathrm{N} \mathrm{kg})$ whereas the latest was obtained from $\mathrm{RF} \times \mathrm{N} 1(56.30 \mathrm{~kg} / \mathrm{N} \mathrm{kg}$ ) (figure $2 \mathrm{k}$ and 1 ).

Table: 10 ANOVA table of NUE

\begin{tabular}{lll}
\hline Source of variation & df & NUE \\
\hline Season & 1 & 5709.06 \\
Replicate(Seasons) & 4 & 752.66 \\
Irrigation & 1 & $139578.21^{*}$ \\
Seasons*Irrigation (Main plot error ) & 1 & 604.58 \\
Nitrogen & 2 & $17466.54 * * *$ \\
Nitrogen*Irrigation & 2 & $6650.21^{* * *}$ \\
Error & 24 & 388.83 \\
$\mathrm{CV}$ & & 14.61 \\
$\mathrm{R}^{2}$ & & 0.95 \\
\hline
\end{tabular}

Signif. codes: 0 '***’ 0.001 '**' 0.01 '*' 0.05 


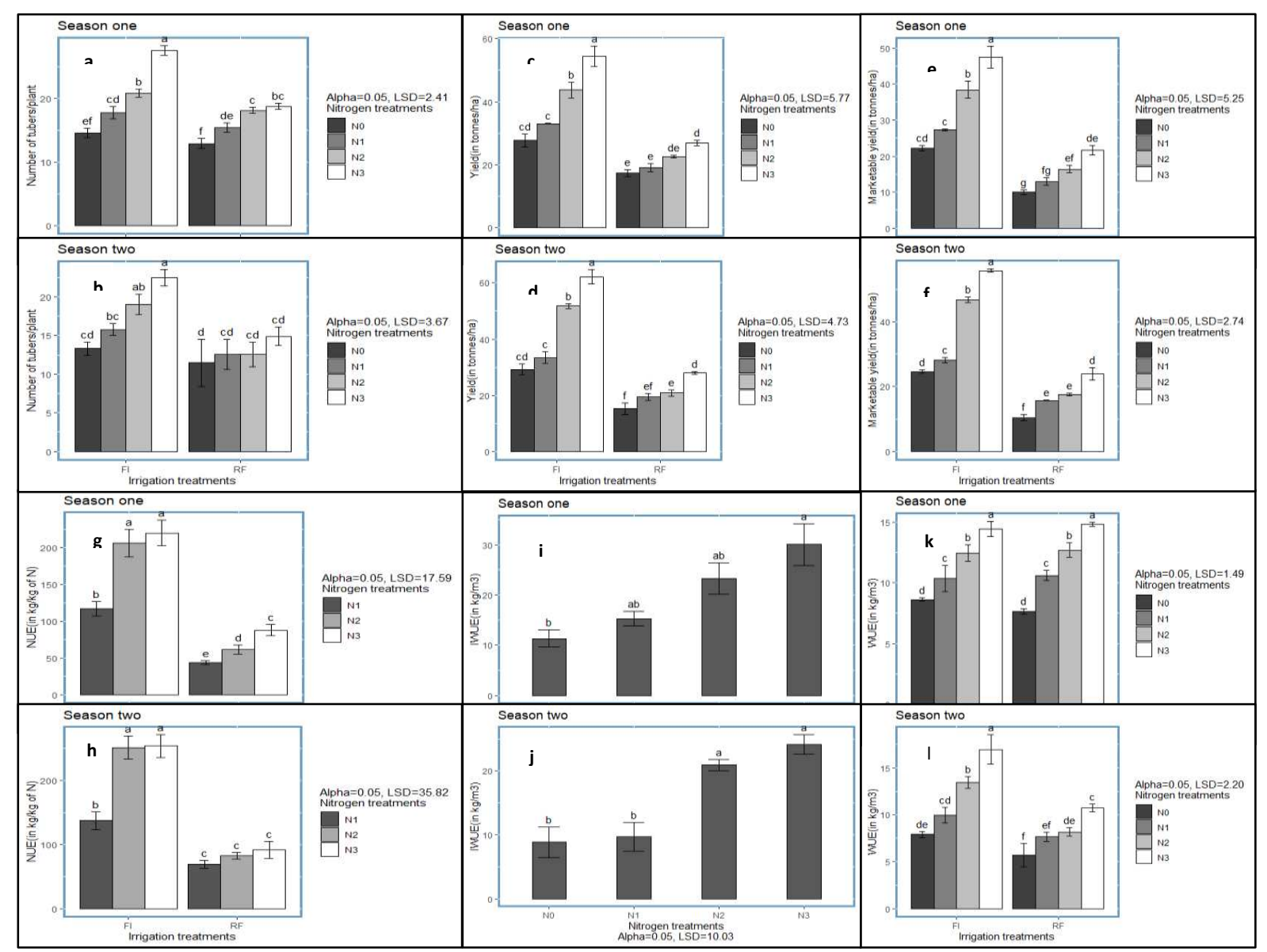

Figure 2: Means separation of number of tubers/plant, tuber yield, marketable yield WUE IWUE and NUE per season at 0.05

\section{Relationship between potato yield, WUE, NUE and $\mathrm{N}$-rate in different irrigation treatments.}

The regression equations and determination coefficients between $\mathrm{N}$-fertilization and tuber yield obtained were, FI: $\mathrm{Y}=0.2033 \mathrm{X}+25.517, \mathrm{R} 2=0.91$ and $\mathrm{Y}=0.2667 \mathrm{X}+25.33, \mathrm{R} 2=0.92$; and $\mathrm{RF}: \mathrm{Y}=0.0689 \mathrm{X}+16.178, \mathrm{R} 2=0.92$; and $\mathrm{Y}=0.0956 \mathrm{X}+14.061, \mathrm{R} 2=0.92$ (all F-values were significant at $\mathrm{P}<0.05)$ for the two seasons respectively. FI showed the highest slope during the two growing seasons (figure $3 \mathrm{a}$ and $\mathrm{b}$ ). The following regression equations and determination coefficients were obtained between WUE and N-fertilization, FI: Y $=0.0389 \mathrm{X}$ $+8.5278, \mathrm{R} 2=0.92$ and $\mathrm{Y}=0.0622 \mathrm{X}+7.3944, \mathrm{R} 2=0.94$ and $\mathrm{RF}: \mathrm{Y}=0.0544 \mathrm{X}+7.9389, \mathrm{R} 2$ $=0.99$ and $\mathrm{Y}=0.03778 \mathrm{X}+5.8556, \mathrm{R} 2=0.99$ (all $\mathrm{F}$-values analysis were significant at $\mathrm{P}<$ 0.05). The highest slope of the regression between WUE vs N-fertilization corresponded to FI during the two growing seasons (figure $3 \mathrm{c}$ and $\mathrm{d}$ ). Between NUE and N-fertilization, the following equations were obtained FI: $\mathrm{Y}=1.4095 \mathrm{X}+48.784, \mathrm{R} 2=0.77$ and $\mathrm{Y}=1.5703 \mathrm{X}+$ 68.108, R2 $=0.69$ and $\mathrm{RF}: \mathrm{Y}=0.6432 \mathrm{X}+4.2973, \mathrm{R} 2=0.99$ and $\mathrm{Y}=0.323 \mathrm{X}+51.189, \mathrm{R} 2$ $=0.96$ (all F-values analysis were significant at $\mathrm{P}<0.05$ ). (figure $3 \mathrm{e}$ and $\mathrm{f}$ ). FI had the highest slope for the two seasons but the coefficient of determinations in FI were lower compared to RF. 
It was found out that a high positive correlation existed between tuber yield and NUE $(\mathrm{r}=0.95$, $\mathrm{P}<0.001)$, yield and WUE $(\mathrm{r}=0.72, \mathrm{P}<0.001)$ and between NUE and WUE $(\mathrm{r}=0.61, \mathrm{P}<$ 0.001 ). All the correlations were significant (figure 4). The strong positive correlation between yield and number of tubers per plant showed that an increase in yield was related to the number of tubers/plant. on the contrary, it was reported that there is no correlation between number of tubers/plant and potato yield (Badr et al., 2012).

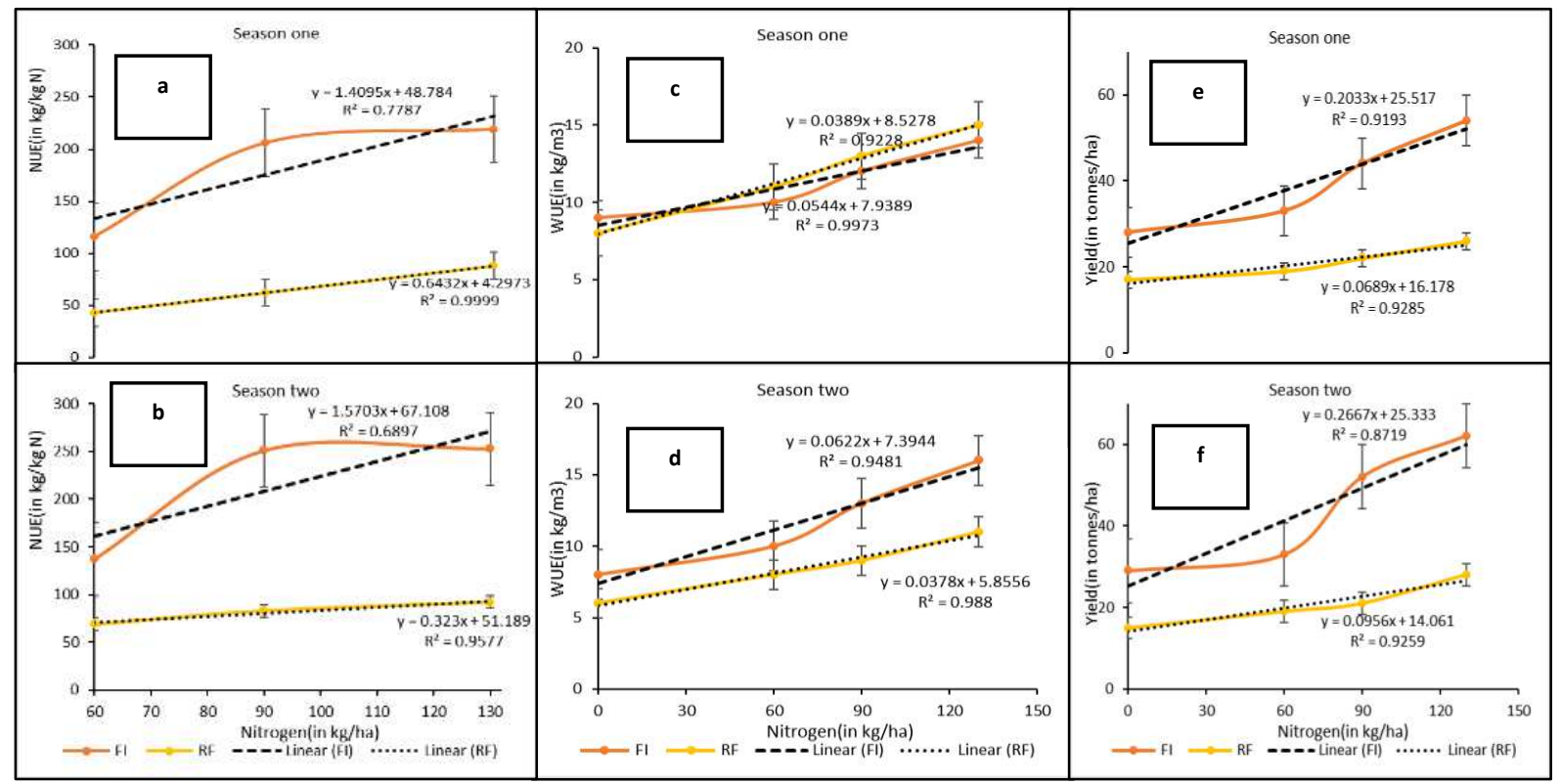

Figure 3: Relationship between potato yield, WUE, NUE and N-rate in different irrigation treatments.

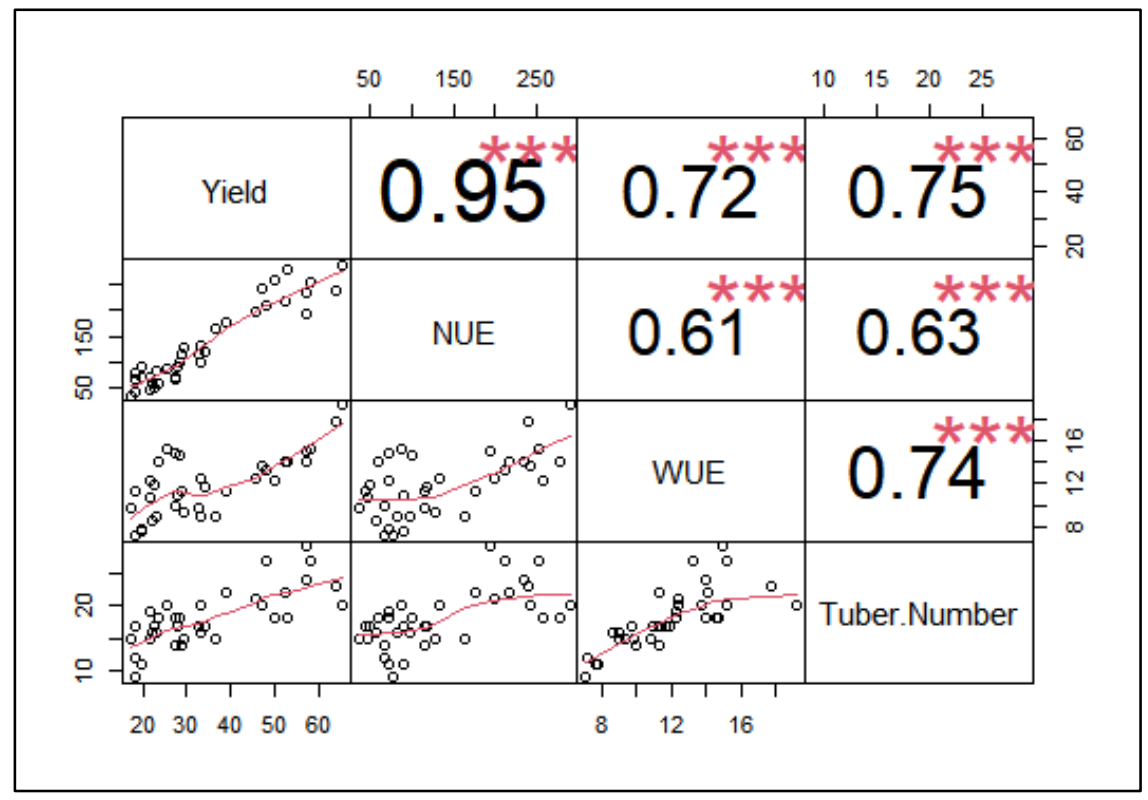

Figure 4: correlation between number of tuber/plant, tuber yield, WUE and NUE

\section{Conclusion}

Yield components of potato were largely more responsive to the interaction effect of irrigation and $\mathrm{N}$-fertilization than a single effect of irrigation and $\mathrm{N}$-fertilization rate. Plant growth was significantly affected by $\mathrm{N}$-fertilization level whereas number of tubers/plant, tuber yield and marketable tuber yield were affected by irrigation $\times \mathrm{N}$-fertilization. Marketable potato tuber yield was greatly increased by supplemental irrigation. The increase of $\mathrm{N}$ rate produces an 
increase in the tuber yield and marketable yield at full irrigation, while under conventional rainfed production, reduced $\mathrm{N}$ rate negatively affects tuber yield and marketable yield. The water was used efficiently in $\mathrm{N} 3(130 \mathrm{~kg} / \mathrm{ha})$. The NUE consistently increased with the increase in $\mathrm{N}$ rate up to $90 \mathrm{~kg} / \mathrm{ha}$ in the two irrigation treatments. There is a high positive correlation between number of tubers/plant, tuber yield, WUE, NUE and WUE. This study highlights the importance of introducing supplemental irrigation in the potato production area in Kenya to keep the soil moisture at the optimum and eliminate the effects of high infiltration rate of mollic Andosols and drought throughout the growing season for an increase in marketable potato yield.

\section{Abbreviations}

NUE: Nitrogen Use Efficiency; HI: Harvest Index; Water Use Efficiency: WUE, Irrigation Water Use Efficiency: IWUE, Full Irrigation: FI, Rain-fed: RF, Kenya Agricultural and Livestock Research Organization: KALRO.

\section{Acknowledgment}

The authors acknowledged the support of MasterCard Foundation at Regional Universities Forum for Capacity Building in Agriculture (MCF@RUFORUM) through its Transforming African Agricultural Universities to Meaningfully Contribute to Africa's Growth \& Development (TAGDev) program.

\section{Authors' contributions}

Satognon contributes to the proposal writing, experiment design fieldwork, data collection, data analysis and interpretation using (version 3.6.3) and writing the manuscript. Prof. Seth F.O. Owido and Dr. Joyce J. Lelei are my supervisors. They assisted in the proposal writing, experiment design fieldwork, data collection, data analysis and interpretation using (version 3.6.3) and writing the manuscript. All authors read and approved the final manuscript.

\section{Funding}

Not applicable to this manuscript.

\section{Availability of data and materials}

We declare that the data and materials used in this manuscript can be

made available as per the editorial policy of the journal.

\section{Ethics approval and consent to participate}

Not applicable to this manuscript.

\section{Consent for publication}

Not applicable to this manuscript.

\section{Competing interests}

The authors declared that there is no competing interest.

\section{Author details}

1 MSc. Student in Soil Science at the Department of Crops, Horticulture and Soils, Faculty of Agriculture, Egerton University, P. O. Box 536-20115, Egerton, Njoro, Kenya.

2 Associate Professor in Soil Physics at the Department of Crops, Horticulture and Soils, Faculty of Agriculture, Egerton University, P. O. Box 536-20115, Egerton, Njoro, Kenya.

3 Senior lecturers in Soil fertility and Soil Microbiology at the Department of Crops, Horticulture and Soils, Faculty of Agriculture, Egerton University, P. O. Box 536-20115, Egerton, Njoro, Kenya. 


\section{References}

Abu El-Fotoh, H. M., Abd-El-Kader, A., and Mansour, F. Y. (2019). Effect of irrigation intervals, antitranspirants, compost and humic acid on growth and yield of sweet potato. Zagazig Journal of Agricultural Research, 46(3), 649-664.

Adavi, Z., Moradi, R., Saeidnejad, A. H., Tadayon, M. R., and Mansouri, H. (2018). Assessment of potato response to climate change and adaptation strategies. Scientia Horticulturae, 228, 91-102.

Afzaal, H., Farooque, A. A., Abbas, F., Acharya, B., and Esau, T. (2020). Precision irrigation strategies for sustainable water budgeting of potato crop in Prince Edward Island. Sustainability, 12(6), 2419.

Ahmadi, S. H., Andersen, M. N., Plauborg, F., Poulsen, R. T., Jensen, C. R., Sepaskhah, A. R., and Hansen, S. (2010). Effects of irrigation strategies and soils on field grown potatoes: Yield and water productivity. Agricultural Water Management, 97(11), 1923-1930.

Allen, R. G., Pereira, L. S., Raes, D., and Smith, M. (1998). Crop evapotranspirationGuidelines for computing crop water requirements-FAO Irrigation and drainage paper 56. Fao, Rome, 300(9), D05109.

Aschonitis, V., Antonopoulos, V., Lekakis, E., Litskas, V., Kotsopoulos, S., and Karamouzis, D. (2013). Estimation of field capacity for aggregated soils using changes of the water retention curve under the effects of compaction. European journal of soil science, 64(5), 688-698.

Ati, A. S., Iyada, A. D., and Najim, S. M. (2012). Water use efficiency of potato (Solanum tuberosum L.) under different irrigation methods and potassium fertilizer rates. Annals of Agricultural Sciences, 57(2), 99-103.

Ati, A. S., Shihab, R. M., Aziz, S. A., and Ahmed, F. H. (2010). Production and water use of potato under regulated deficit irrigation treatments. Annals of Agricultural Science (Cairo), 55(1), 123-128.

Badr, M., El-Tohamy, W., and Zaghloul, A. (2012). Yield and water use efficiency of potato grown under different irrigation and nitrogen levels in an arid region. Agricultural Water Management, 110, 9-15.

Banerjee, H., Ray, K., Sarkar, S., Puste, A., Mozumder, M., and Rana, L. (2015). Impact of nitrogen nutrition on productivity and nutrient use efficiency of potato (Solanum tuberosum L.) in an inceptisol of West Bengal, India. SAARC Journal of Agriculture, $13(2), 141-150$.

Bauder, T. A., Waskom, R., Sutherland, P., and Davis, J. (2011). Irrigation water quality criteria. Colorado State University. Libraries,

Begum, M., Saikia, M., Sarmah, A., Ojah, N. J., Deka, P., Dutta, P. K., and Ojah, I. (2018). Water management for higher potato production: a review. Int. J. Curr. Microbiol. App. Sci, 7(5), 24-33.

Blake, G. (1965). Bulk density. p. 374-390. CA Black et al.(ed.). Methods of soil analysis. Part 1. Agron. Monogr. 9. ASA, Madison, WI. Bulk density. p. 374-390. In CA Black et al.(ed.) Methods of soil analysis. Part 1. 1st ed. Agron. Monogr. 9. ASA, Madison, WI.,

Bouyoucos, G. J. (1962). Hydrometer method improved for making particle size analyses of soils 1. Agronomy Journal, 54(5), 464-465.

Bryan, E., Ringler, C., Okoba, B., Roncoli, C., Silvestri, S., and Herrero, M. (2013). Adapting agriculture to climate change in Kenya: Household strategies and determinants. Journal of environmental management, 114, 26-35.

Darabad, G. R. (2014). Determining effects of irrigation stress on growth and yield of potato cultivars in Ardabil cold region. Journal of Biodiversity and Environmental Sciences (JBES) Vol, 4, 318-326. 
Djaman, K., Irmak, S., Koudahe, K., and Allen, S. (2021). Irrigation Management in Potato (Solanum tuberosum L.) Production: A Review. Sustainability 2021, 13, 1504. In: s Note: MDPI stays neutral with regard to jurisdictional claims in published ....

Erdem, T., Erdem, Y., Orta, H., and Okursoy, H. (2006). Water-yield relationships of potato under different irrigation methods and regimens. Scientia Agricola, 63(3), 226-231.

FAOSTAT. (2020). Food and Agriculture Organization of the United Nations. statistical database. Rome.

Farrag, K., Abdrabbo, M. A., and Hegab, S. A. (2016). Growth and productivity of potato under different irrigation levels and mulch types in the North West of the Nile Delta, Egypt. Middle East Journal of Applied Sciences, 6(04), 774-786.

Godebo, D. D., and Belay, B. D. A. S. T. (2020). Effect of Nitrogen Fertilizer (Urea) Rate Application on Growth Performance of Potato (Solanum Tuberosum L.) on Vertisols of Central Highland of North Shewa, Ethiopia.

Ierna, A., and Mauromicale, G. (2018). Potato growth, yield and water productivity response to different irrigation and fertilization regimes. Agricultural Water Management, 201, 21-26.

Jensen, M. E., and Allen, R. G. (2016). Evaporation, evapotranspiration, and irrigation water requirements. Task Committee on Revision of Manual 70.

Kimathi, S. M., Ayuya, O. I., and Mutai, B. (2021). Adoption of climate-resilient potato varieties under partial population exposure and its determinants: Case of smallholder farmers in Meru County, Kenya. Cogent Food \& Agriculture, 7(1), 1860185.

Koch, M., Naumann, M., Pawelzik, E., Gransee, A., and Thiel, H. (2020). The importance of nutrient management for potato production part I: Plant Nutrition and Yield. Potato research, 63(1), 97-119.

Leal Filho, W., Esilaba, A. O., Rao, K. P., and Sridhar, G. (2015). Adapting African agriculture to climate change: Springer.

Li, W., Xiong, B., Wang, S., Deng, X., Yin, L., and Li, H. (2016). Regulation effects of water and nitrogen on the source-sink relationship in potato during the tuber bulking stage. PloS one, 11(1), e0146877.

Mattar, M. A., El-Abedin, T. K. Z., Al-Ghobari, H. M., Alazba, A., and Elansary, H. O. (2021). Effects of different surface and subsurface drip irrigation levels on growth traits, tuber yield, and irrigation water use efficiency of potato crop. Irrigation Science, 1-17.

Mburu, H., Cortada, L., Haukeland, S., Ronno, W., Nyongesa, M., Kinyua, Z., . . Coyne, D. (2020). Potato cyst nematodes: a new threat to potato production in East Africa. Frontiers in Plant Science, 11, 670.

McEwan, M., Spielman, D., Okello, J., Hareau, G., Bartle, B., Mbiri, D., . . . Gonzalez, L. (2021). Exploring the regulatory space for improving availability, access and quality of vegetatively propagated crop seed: potato in Kenya.

Meligy, M. M., Abou-Hadid, A., El-Shinawy, M. Z., and El-Behairy, U. (2020). Impact of climate change on water requirements and the productivity on potato crop. Egyptian Journal of Horticulture, 47(1), 57-68.

Metwaly, E., and El-Shatoury, R. (2017). Impact of foliar application with salicylic acid on growth and yield of potato (Solanum tuberosum L.) under different irrigation water quantity. Journal of Plant Production, 8(10), 969-977.

Motsara, M., and Roy, R. N. (2008). Guide to laboratory establishment for plant nutrient analysis (Vol. 19): food and agriculture organization of the united nations Rome.

Muthoni, J., Nyamongo, D. N., and Mbiyu, M. (2017). Climatic change, its likely impact on potato (Solanum tuberosum L.) production in Kenya and plausible coping measures. International Journal of Horticulture, 7. 
Nowacki, W. (2018). Water in potato production, problems and challenges. Ecological Engineering \& Environmental Technology, 19(6), 14-25.

Okalebo, J. R., Gathua, K. W., and Woomer, P. L. (2002). Laboratory methods of soil and plant analysis: a working manual second edition. Sacred Africa, Nairobi, 21.

Ospina, C., van Bueren, E. L., Allefs, J., Engel, B. v., Van der Putten, P., Van der Linden, C., and Struik, P. (2014). Diversity of crop development traits and nitrogen use efficiency among potato cultivars grown under contrasting nitrogen regimes. Euphytica, 199(1), 13-29.

Paredes, P., D’Agostino, D., Assif, M., Todorovic, M., and Pereira, L. S. (2018). Assessing potato transpiration, yield and water productivity under various water regimes and planting dates using the FAO dual Kc approach. Agricultural Water Management, 195, 11-24.

Salter, P. J., and Goode, J. E. (1967). Crop responses to water at different stages of growth. Crop responses to water at different stages of growth.

Sasani, G., Patel, C. K., Patel, R., Patel, N., and Patel, S. (2006). Efficient use of water and fertilizers through drip fertigation in potato. Potato Journal, 33(3-4).

Scherer, T. F., Seelig, B., and Franzen, D. (1996). Soil, water and plant characteristics important to irrigation.

Setu, H., and Mitiku, T. (2020). Response of potato to nitrogen and phosphorus fertilizers at Assosa, western Ethiopia. Agronomy Journal, 112(2), 1227-1237.

Sharma, H., Shukla, M. K., Bosland, P. W., and Steiner, R. (2017). Soil moisture sensor calibration, actual evapotranspiration, and crop coefficients for drip irrigated greenhouse chile peppers. Agricultural Water Management, 179, 81-91.

Shunka, E., Chindi, A., Gebremedhin, W. G., Seid, E., and Tessema, L. (2017). Determination of optimum nitrogen and potassium levels for potato production in central high lands of Ethiopia. Open Agriculture, 2(1), 189-194.

Taiy, R. J., Onyango, C., And Nkurumwa, A. (2017). Climate Change Challenges and Knowledge Gaps in Smallholder Potato Production: The Case of Mauche Ward in Nakuru County, Kenya. International Journal of Agricultural Science and Research (IJASR), 7(4), 719-730.

Tang, J., Wang, J., Fang, Q., Wang, E., Yin, H., and Pan, X. (2018). Optimizing planting date and supplemental irrigation for potato across the agro-pastoral ecotone in North China. European Journal of Agronomy, 98, 82-94.

Tolessa, E. S. (2019). A review on water and nitrogen use efficiency of potato (Solanum tuberosum L.) inrelation to its yield and yield components. Archives of Agriculture and Environmental Science, 4(2), 119-132.

Tolessa, E. S., Belew, D., and Debela, A. (2017). Effect of nitrogen rates and irrigation regimes on nitrogen use efficiency of potato (Solanum tuberosum L.) in southwest Ethiopia. Science, 2(3), 170-175.

Waaswa, A., Oywaya Nkurumwa, A., Mwangi Kibe, A., and Ngeno Kipkemoi, J. (2021). Climate-Smart agriculture and potato production in Kenya: review of the determinants of practice. Climate and Development, 1-16.

Waqas, M. S., Cheema, M. J. M., Hussain, S., Ullah, M. K., and Iqbal, M. M. (2021). Delayed irrigation: An approach to enhance crop water productivity and to investigate its effects on potato yield and growth parameters. Agricultural Water Management, 245, 106576.

Wilcox, L. (1955). Classification and use of irrigation waters: US Department of Agriculture. Zhang, Y.-L., Wang, F.-X., Shock, C. C., Yang, K.-J., Kang, S.-Z., Qin, J.-T., and Li, S.-E. (2017). Effects of plastic mulch on the radiative and thermal conditions and potato growth under drip irrigation in arid Northwest China. Soil and Tillage Research, 172, $1-11$. 
Figures

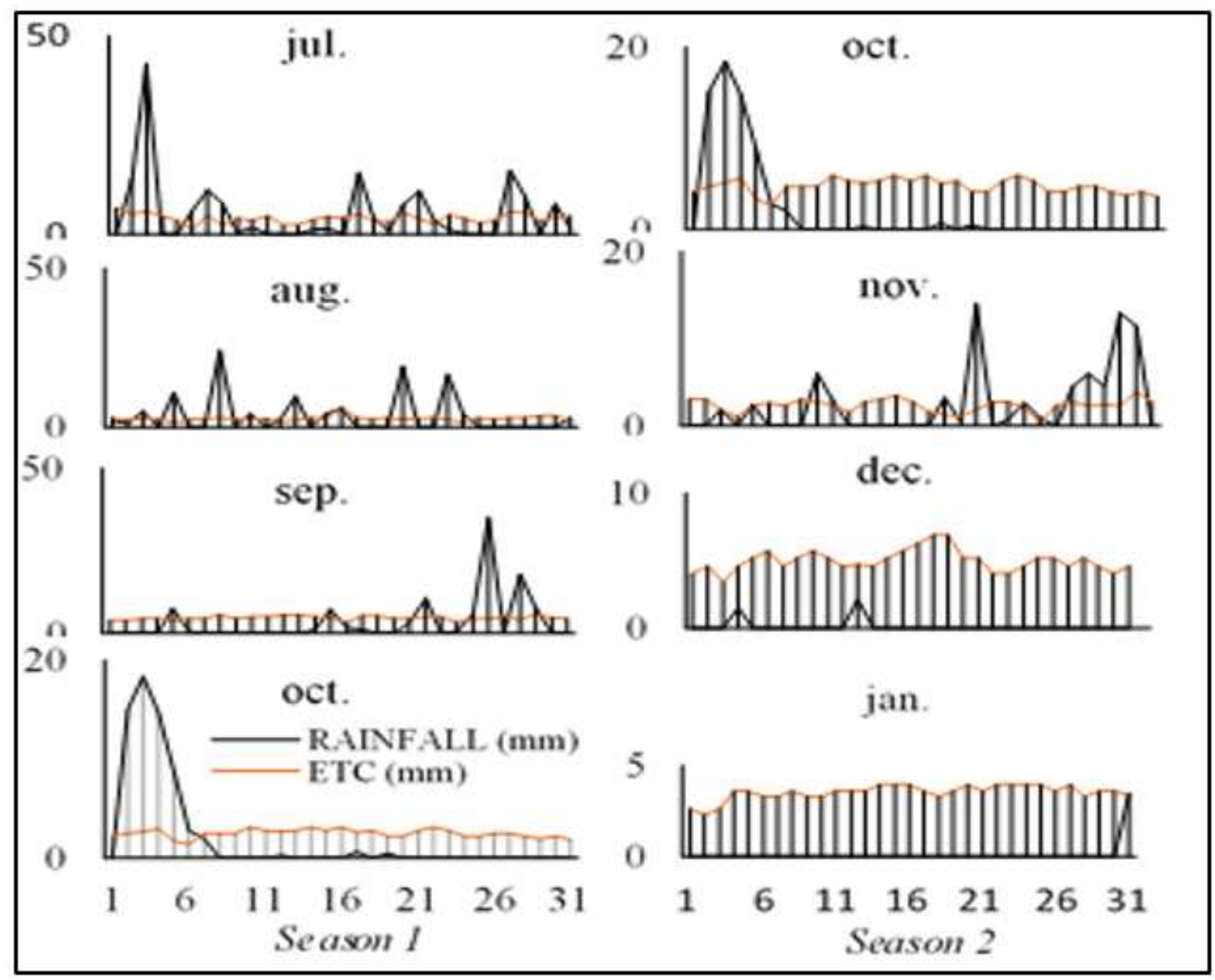

Figure 1

Daily precipitation and ETC of the growing seasons 


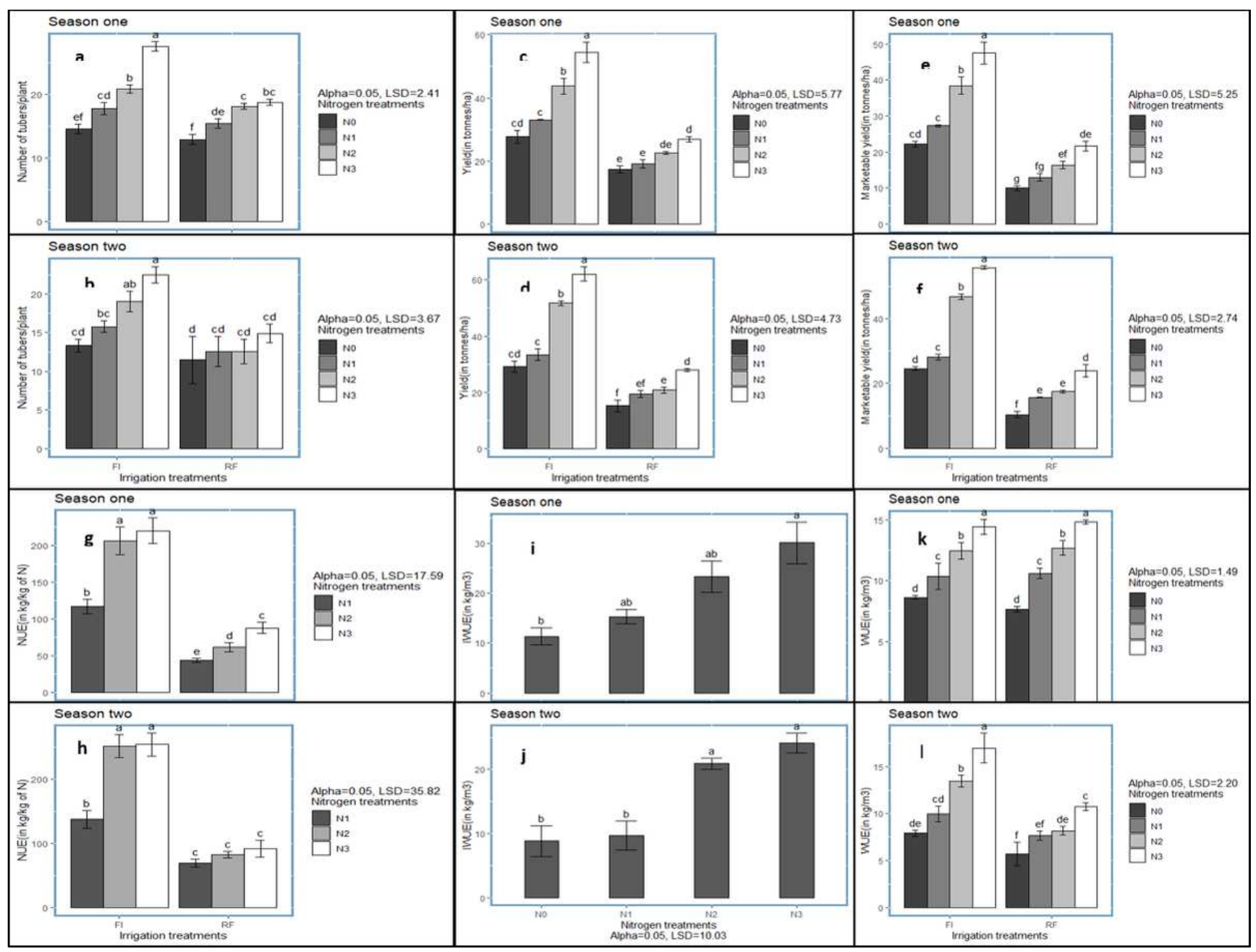

Figure 2

Means separation of number of tubers/plant, tuber yield, marketable yield WUE IWUE and NUE per season at 0.05 


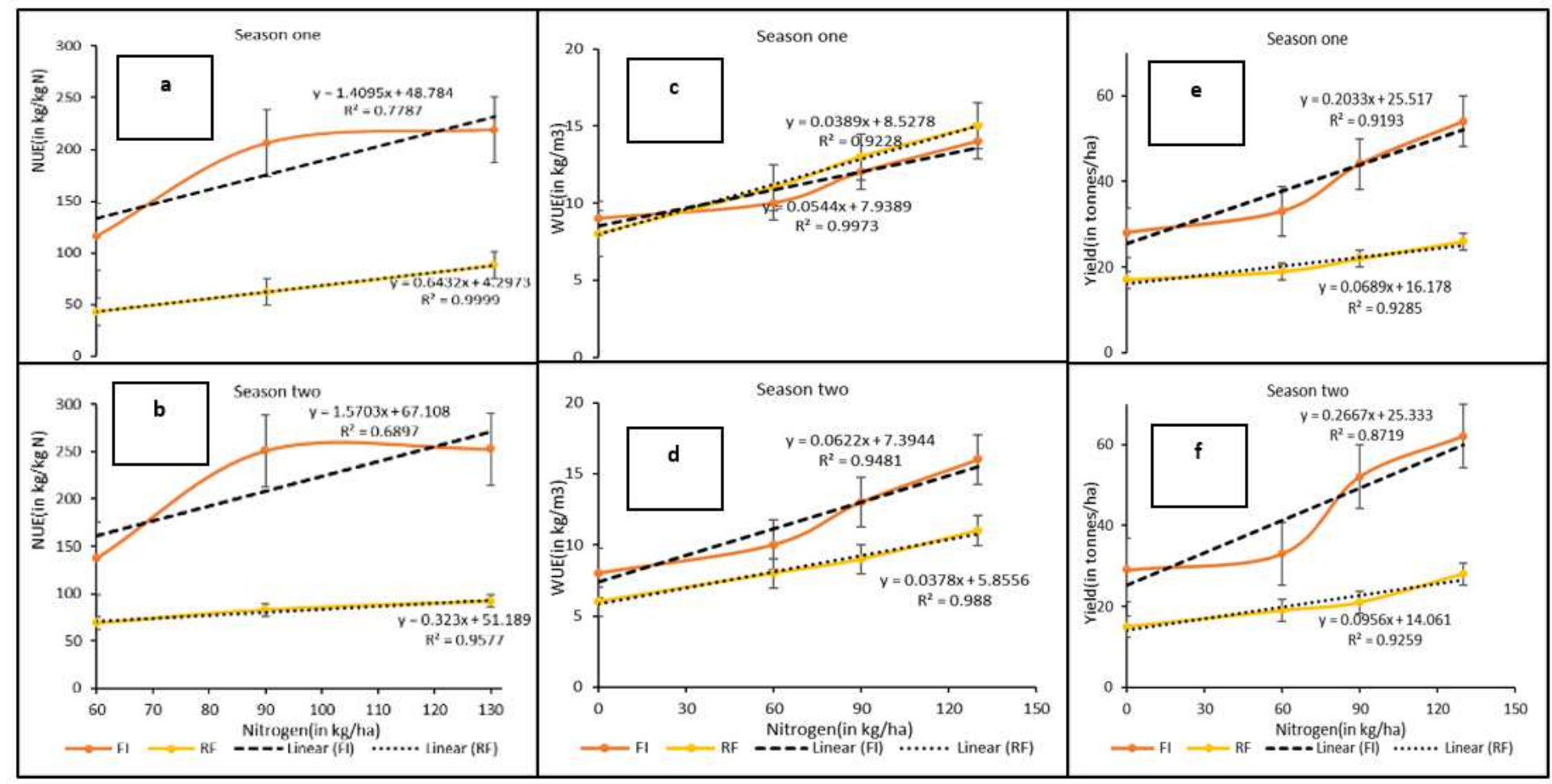

Figure 3

Relationship between potato yield, WUE, NUE and N-rate in different irrigation treatments 


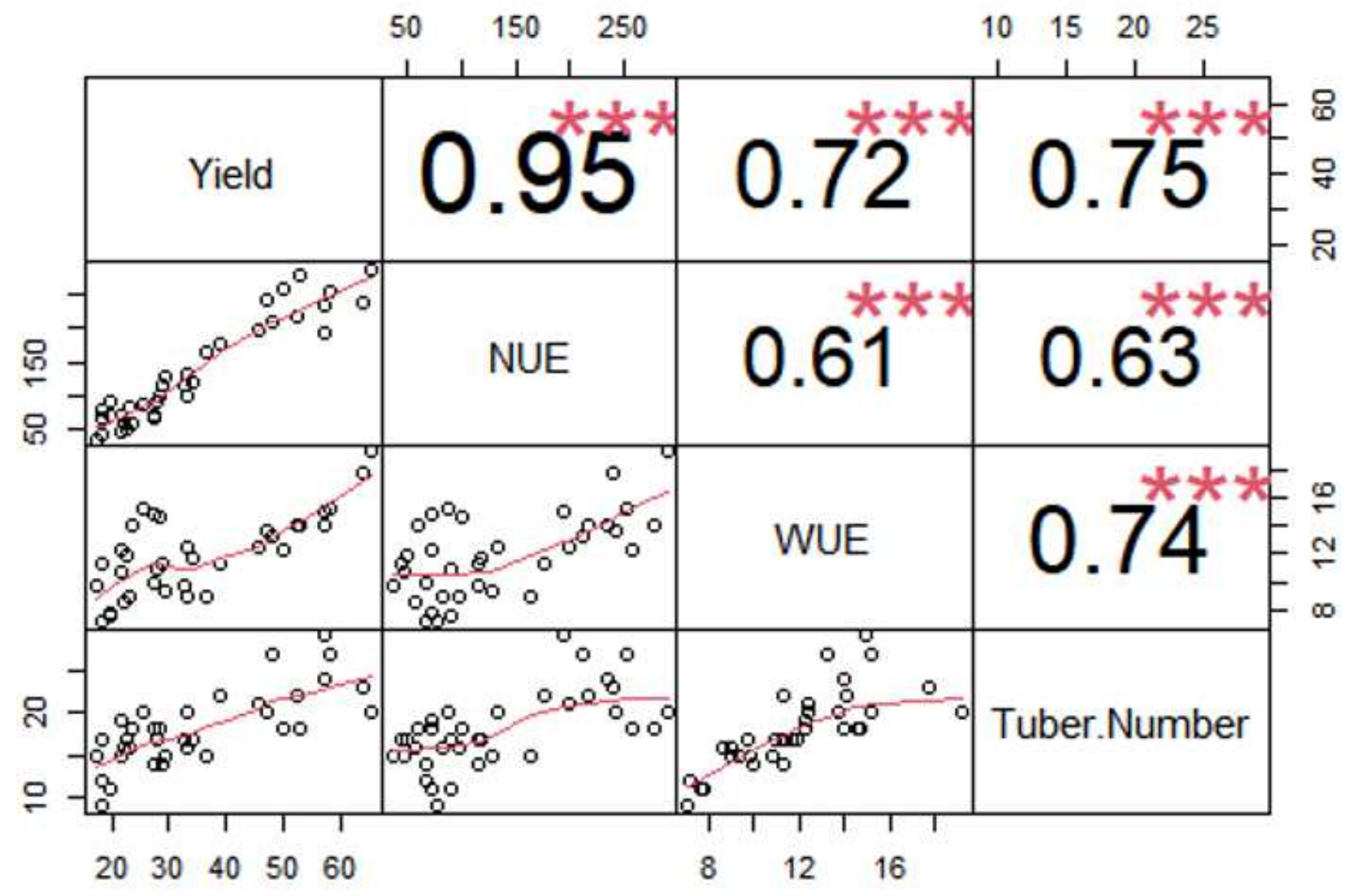

Figure 4

correlation between number of tuber/plant, tuber yield, WUE and NUE

\section{Supplementary Files}

This is a list of supplementary files associated with this preprint. Click to download.

- dataset1.xlsx

- dataset2.xlsx 